\title{
What Do Indigenous Communities Think of the CSR Practices of Mining Companies?
}

\author{
Kevin Kepore \\ CPA Papua New Guinea \\ Colin Higgins \\ Deakin University, Australia \\ Robert Goddard \\ Massey University, New Zealand
}

\begin{abstract}
This paper examines how one indigenous community in the Western Province of Papua New Guinea (PNG) views the social responsibility initiatives of OK Tedi Mining Ltd (OTML). This mining operation has been controversial since its inception, and various operators of the mine have sought to engage the community and to undertake a number of CSR-related projects. Insights gained from four focus groups amongst the Ok Tedi River indigenous communities show that while some members of the community are satisfied with the company's efforts at the macro level, many have reservations about the effectiveness of the programs at the micro level on the village and family unit. The implementation of CSR activities are slow and in many instances do not effectively address stakeholder concerns.
\end{abstract}

\section{Keywords}

Corporate Social Responsibility, Stakeholders, Indigenous Community.

\section{Introduction}

For most of the past fifty years, academics have debated the social responsibilities that business should assume (Bowen, 1953; Carroll, 1999), and managers have struggled to implement policies that satisfy these multiple expectations. One framework that has enjoyed some traction is stakeholder theory - or the idea that business organisations have responsibilities to groups and organisations that

Copyright (C) 2013Victoria University. This document has been published as part of the Journal of Business Systems, Governance and Ethics in both online and print formats.

Educational and non-profit institutions are granted a nonexclusive licence to utilise this document in whole or in part for personal or classroom use without fee, provided that correct attribution and citation are made and this copyright statement is reproduced. Any other usage is prohibited without the express permission of the publisher. are affected by its operations (Freeman, 1984). Business ethics academics are drawn to its normative foundations (Hasnas, 1998), and managers intuitively recognise the potential stakeholders can have on reputation and organisational legitimacy (Beaver, 1999). Stakeholder theory incorporates descriptive, instrumental and normative perspectives (Donaldson \& Preston, 1995), offering an alternative to the traditional profit maximising theory of the firm. 
Stakeholder theory is not without its critics - in many ways it has been easier to consider in theory, than to implement in practice. One challenge is practical - how do managers reconcile conflicting stakeholder demands (Kerr, 1996)? Another is whether stakeholders are always right - is there more to being socially responsible than taking in to account the demands of those powerful or organised enough to be heard (Clarkson, 1995)? While some scholars have asserted that there are different levels of stakeholders - including primary and secondary stakeholders (Preston, 1990), defining 'who and what really counts' remains a challenge (Mitchell, Agle, \& Wood, 1997).

One significant theoretical weakness with stakeholder theory is the lack of the views of stakeholders themselves. Mostly, stakeholder perspectives are considered in the negative, and largely assumed. That is, they are conceptualised as a source of potential trouble for business, and it is assumed they are sufficiently powerful and organised to act in the face of poor business behaviour. Certainly, the literature is replete with cases of high-profile stakeholder action - examples of stakeholder challenges to Nike, Shell, Walmart, and Nestle are numerous (see, for illustration, Bendell, 2000 and the chapters contained therin). What is less considered are the views of specific stakeholders in light of socially responsible practices initiated by companies. Do the socially responsible practices put in place measure up? Are they sufficient, valued and seen as effective?

In this paper we present the findings of four focus groups held with an indigenous community alongside the OK Tedi River in Papua New Guinea, downstream from the controversial mine that bears its name. We engaged representatives of the Yonggom community - a community that falls outside OK Tedi's Mine Lease Agreement zone, but which has been found to be significantly affected by the mine's operations (Kirsch, 1992). We introduce a stakeholder perspective to considerations about the value and effectiveness of socially responsible business behaviour.

In the next section we provide a brief overview of how social responsibility has been theorised, raising in particular ambiguities about what CSR is meant to achieve. We then describe our research site - the issues associated with mining companies and the situation of the OK Tedi Mining Company in Papua New Guinea. We then present the results of our focus groups - emphasising three key themes that emerged. A discussion and conclusion section summarises our points.

\section{Literature Review and Case-Study Background}

Corporate Social Responsibility (CSR) is an elusive concept - full of ambiguity for those who seek to define it, and also for those who try to practice it (Dahlsrud, 2008). At issue are different perspectives about its normative foundations and its fundamental contributions (Windsor, 2001, 2006).

Many CSR scholars have emphasised its normative foundations, and have attempted to institutionalise a new moral language for business. The basic position is that ethical theory should guide the behaviour of managers, and should be used to evaluate the appropriateness of business outcomes (Den

Copyright (C) 2013Victoria University. This document has been published as part of the Journal of Business Systems, Governance and Ethics in both online and print formats. Educational and non-profit institutions are granted a nonexclusive licence to utilise this document in whole or in part for personal or classroom use without fee, provided that correct attribution and citation are made and this copyright statement is reproduced. Any other usage is prohibited without the express permission of the publisher.
Uyl, 1984). Early contributions stressed a 'social contract' that sought to tie social and environmental outcomes to the freedom extended to private business organisations by 'society' (Bowie, 1991; Donaldson, 1982). Normative perspectives assert that, irrespective of economic outcomes, business organisations are social actors that have obligations to respect the rights of others. Much of this work assumes fundamental changes in the business and society relationship are necessary (Windsor, 2006). 
Others see CSR as entirely consistent with the current business system, and seek to blend economic and social/ethical issues. Firms can still maximise profits - indeed CSR is often seen as the means by which they can do so. Much of the CSR scholarship over the past thirty years has investigated the CSR-Financial performance relationship (Margolis \& Walsh, 2003) - such that many now take for granted that a 'business case' for CSR exists (Wry, 2009). Conceptually, several 'integrated' CSR frameworks have attempted to blend the various demands on business. Probably the framework that has received most attention is Carroll's pyramid of corporate responsibility. According to this model, business organisations have economic, legal, ethical and discretionary responsibilities (Carroll, 1979). The assumption has been a mutually beneficial relationship between economic and social/normative outcomes.

Aside from, and running in parallel to, theoretical perspectives about CSR has been the development of a number of socially responsible practices. While some scholars have attempted to conceptualise these initiatives - most notably by way of corporate social performance (Wartick \& Cochrane, 1985; Wood, 1991a, 1991b), but also Frederick's corporate social responsiveness (CSR2) (Frederick, 1994) - socially responsible practices have been distinctively practice-led. Firms now engage in a wide range of social and environmental activities - ostensibly geared toward fulfilling their responsibilities. Analyses by Kinder, Lydenberg and Domini \& Co (see Michelon, Boesso, \& Kumar, 2013) provide an overview of common socially responsible business practices. Many initiatives have arisen from voluntary global codes (eg the UN Global Compact), and are specified as part of sustainability reporting frameworks (eg the Global Reporting Initiative), and have emerged through various socially responsible business awards (McIntosh, Thomas, Leipziger, \& Coleman, 2003). Studies of the 'most' socially responsible companies show that firms in almost all industries engage in socially responsible business practices. Some activities - such as sustainability reporting, stakeholder engagement, business-community partnerships, philanthropy and various employment related initiatives (such as the employment of disadvantaged people) are common across many different industries (Michelon et al., 2013).

In the mining (and other extractive) industries, social responsibility has become fairly well institutionalised - driven in part by well documented controversies. Of concern have been the impacts of large multinational mining companies (MNMCs) on the environment (Garvin, McGee, Smoyer-Tomic, \& Ato Aubynn, 2009) - particularly waste management; indigenous community relations; and aspects of socio-economic development (Banks, 2002). Mining companies tend to operate in some of the most isolated - but also some of the most pristine environments - and stakeholders have lamented the irreversible impacts that mining causes to these landscapes (Annadale \& Taplin, 2003). In terms of indigenous issues, the extraction of mineral resources displaces indigenous people from their traditional lands and affects their cultural and social lives. It is an activity of business in which the whole ways of life for the indigenous people are altered permanently. Concerns over socio-economic development centre on mining operations in developing countries where economic development is a high priority, but social and infrastructure services are basic and often weak public policy and legislation governing the extraction of mineral resources prevails (Yakovleva, 2005). It is now taken-for-granted and expected that a range of social and environmental initiatives are undertaken to address some of the adverse impacts of mining operations.

\section{The Research Site and Approach}

We explore the issues associated with the socially responsible initiatives put in place by the OK Tedi Mining Company in Papua New Guinea. The economy of Papua New Guinea (PNG) is dominated by the mining and oil sectors, making up approximately $70 \%$ of exports and about $25 \%$ of gross domestic product (Banks, 2002; Imbun 2007). The mining industry in PNG and the behaviour of the Government in relation to mining has been controversial (Harper and Israel, 1999). The Multinational Mining Companies (MNMCs) have been accused of exerting considerable pressure over the Government - often lobbying extensively over environmental and mining laws (Harper and Israel, 
1999), and the Government is seen as capitulating - driven by the need to attract and retain economic outcomes. The enactment of statutory laws by the PNG Government that deny customary resource owners the right to sue for compensation in the courts is a case in point (Kalinoe and Kuwimb, 1997).

The Ok Tedi Mining Company (OTML) operation is PNG's highest profile mining-related controversy. The gold and copper mine is located in the Star Mountains in Western Province of Papua New Guinea (See appendices A \& B). The project was the country's first major post-independence mining operation, developed as part of a national strategy to generate revenue for the State and create employment opportunities for its people. It is managed by Ok Tedi Mining Limited (OTML) under a consortium agreement between shareholders. BHP Billiton originally owned $52 \%$ of the mine, but in 2002 it transferred these shares to the Papua New Guinea Sustainable Development Program (PNGSDP) and pulled out of operations. OTML's shareholders comprise PNGSDP (52 per cent), Inmet Mining Ltd (18 per cent) and the PNG Government (30 per cent).

The Ok Tedi mine has had a significant economic effect at both the local and national levels. The company has provided much need revenue in the form of taxes and dividends (Imbun, 2007), and it employs approximately 2,000 people with a further 1,500 by contractors servicing the company. Over $90 \%$ of the employees are PNG citizens with about 800 coming from within a 40 kilometre radius of the mine (Higgins, 2001). According to Morrison (2007) OTML has contributed K300 million in community infrastructure - benefitting local business as well as agricultural programs. Morrison further estimates that more than 50,000 people depend on the economic activity that the mine generates. The benefits provided by mining companies in the form of infrastructure development, education and health services as well as financial benefits are acknowledged by local communities.

The OK Tedi Mine has been controversial since its inception. Prior to operations commencing, the PNG government gave approval for the dumping of mine tailings into the Ok Tedi River, following the collapse of a tailing dam during the early construction phase (Harper and Israel, 1999; Morrison, 2007) and extensive lobbying by the company. The company threatened to quit operations if the approval was not granted (Harper and Israel, 1999), and the Government appears to have made several other compromises to secure desperately needed revenue. Since then, the Ok Tedi and Fly River pollution has become an international environmental issue (Evans 2001; Imhof, 1996; Jennings, 1995). OTML discharges on average 80,000 tonnes of mine waste per day into the Ok Tedi River which eventually joins the Fly some $150 \mathrm{~km}$ from the mine (Kirsch, 1992; Imhof, 1996). The effects of the discharge are experienced up to some $800 \mathrm{~km}$ downstream from the mine site.

From a social perspective, adequate nutrition and protein intake has become an area of concern (Kirsch, 1992) as people consider the fish and other river sourced protein to be contaminated by toxic chemicals. In addition, though the mine operation has brought about increased medical benefits to the villages, it has also brought with a range of outsiders and an influx of introduced diseases - including tuberculosis and sexually transmitted infections (Kirsch, 1992). Unemployment among the Lower Ok Tedi people also appears to be an issue as they transition from a subsistence economy. Even through the mine operation has generated considerable employment, it has not been evenly distributed. The number of Yonggom employed at the mine site is low (Kirsch, 1992). Economically, the distribution of the gains from the mine have failed to reach the people living in the Lower Ok Tedi and Fly rivers (Kirsch, 1992).

\section{The Indigenous community of Western Province}

The Ok Tedi indigenous community comprises numerous villages stretching approximately 150 kilometres along the Ok Tedi River system. Prior to the commencement of mining, the indigenous community were predominately subsistence farmers (Kirsch, 1992). Their livelihood was sustained through the use of land resources and a working knowledge of the environment. Anthropologist Stuart Kirsch (1992) maintained the company's operations greatly impacted those living in this region, particularly the Yonggom community that fell outside the Mine Lease Agreement (MLA) 
zone. This community did not originally derive any benefit from OTML, unlike the Wopkaimin people who live by the mine site and are deemed by both the company and the government to be the immediate beneficiaries of compensation (Morrison, 2007). It was only as a result of a lawsuit filed in 1994 by the landowners from the Lower Ok Tedi and Fly rivers against the then BHP Ltd that the plight of the Lower Ok Tedi people was first highlighted to the world.

\section{Research Approach and Design}

The main data for this study is derived from four focus groups held in the OK Tedi River region in late November 2007. Participants were recruited by one of the authors using community networks with help from the Community Relations Office at OTML in towns between Tabubil and the river port town of Kiunga (see Appendix A). A combination of purposeful approaches (Morgan, 1997) to community leaders was combined with snowball sampling to recruit a sufficient cross section of community members. The aim of our participant selection was not necessarily representation - but to gather together sufficient numbers of local indigenous people to enable the full spectrum of issues to surface.

According to Morgan (1997), focus groups are basically group interviews to produce data and insights that would be less accessible without the interaction found in groups. In particular, they are valuable for gaining an insight in to the opinions, beliefs and values of a particular segment of the population (Davidson and Tolich, 2003). Focus group research uses group discussions to recognise and explore the thoughts and perceptions about a particular area of interest. They have particular value for uncovering direct evidence about similarities and differences in the participants' opinions and experiences about a particular event or phenomena (Morgan, 1993).

Of the four focus groups, one was held in Kiunga and the other three in different villages along the river. Each village has approximately 150 to 200 people, whereas Kiunga has a population of about 10,000 people. The four focus groups consisted of between eight and ten people, with a total of 37 participants. The focus groups were conducted in Pidgin which is the common language spoken by almost all Papua New Guineans and were taped and transcribed (with permission). One of the authors is a native speaker, and undertook the focus groups and the translation.

The eight questions discussed in the four focus groups were structured to obtain an understanding of the indigenous community's perception on CSR strategies applied by OTML (see appendix C). These questions were used as prompts to facilitate discussion and to keep the insights generated focused on key themes.

The principles and processes of thematic analysis were used to code and interpret the data. According to Boyatzis (1998) thematic analysis is the process of identifying themes or concepts that are in the data. The researcher systematically builds an account of what has been discussed, observed and recorded - initially by recognising the codable moments or sensing themes (Boyatzis, 1998). In this study we followed the six phases of thematic analysis (see table 1) as presented by Braun and Clarke (2006). 
Table 1. Phases of thematic analysis

Phase Description of the process

1. Familiarizing yourself with your data

2. Generating initial codes

3. Searching for themes

4. Reviewing themes

5. Defining and naming themes

6. Producing the report
Transcribing data (if necessary), if necessary reading and re-reading the data, noting down initial ideas

Coding interesting features of the data in a systematic fashion across the entire data set, collating data relevant to each code.

Collating codes into potential themes, gathering all data relevant to each potential theme.

Checking if the themes work in relation to the coded extracts (Level 1) and the entire data set (Level 2), generating a thematic 'map' of the analysis.

Ongoing analysis to refine the specifics of each theme, and the overall story the analysis tells, generating clear definitions and names for each theme.

The final opportunity for analysis. Selection of vivid, compelling extract examples, final analysis of selected extracts, relating back of the analysis to the research question and literature, producing a scholarly report of the analysis.

Source: Braun and Clarke (2006)

\section{Indigenous community perceptions on OTML's CSR strategies}

Three major themes emerged from the focus group discussions.

\section{Theme One: Anger, disappointment and frustration}

Participants identified and acknowledged a number of important community projects initiated by the company, but overwhelmingly their feelings towards the activities of OTML are of disappointment, anger and frustration. This reaction relates to aspects of the company's core operations, rather than the specific details of their CSR initiatives. The issue of how mine tailings are discharged, and their impacts on the river which have destroyed their primary source of livelihood is a major concern. Shared within this theme was concern that the company was not adequately assisting local communities to live within the mine impacted environment. One participant stated:

...we cannot do gardening because bananas, sagos, taro and yams can no longer grow beside the rivers. Also there is no fish in the river anymore. These problems have come about because of the mine polluting our river but the company is not doing anything to help us (Group 1, p. 2).

Thus, feelings centred on the immediate difficulties faced by communities along the Lower Ok Tedi River. In outlining the difficulties they faced, the tone of language used, the expressions on the 
participants' faces, and their body language provided a glimpse of frustration and resentment at the company.

OTML maintains that the river is safe to drink and that there is adequate fish stock in the river (Higgins, 2001) and Breen (2007) continued to advocate this position when he stated on 29 October 2007:

"There are fish in the system and they are edible. The water is still drinkable so long as the areas of evident oxidation are avoided. The produce from gardens is still safe to eat".

When asked whether the company's position regarding the status of the river was correct, all members of the focus groups were angered by the company's claim. One participant responded to this statement in the following terms:

...the company is not telling the truth. You can see for yourself what has happened to the river. Before mining operation the river was very clear. We could see fish and turtles swimming in it. Now we cannot see anything. What is running down is a black, grey muddy river (Group 4, p.2).

With regard to the river, the participants also wanted to know whether the river would return to normal status anytime in the future. They were concerned that the company was not adequately addressing the environmental issues including flooding of the river banks responding in the following manner:

...the river is flooding more often these days. The mud from the river is washed into our gardens killing our taros, yams and sago palms. We have told the company our problems but they never listen to us. They must listen to us and help us settle in other places where it is safe (Group 1, p.6).

...we are telling them what we want done in our villages, but the company people do not listen. They always come and tell us about their plans and projects (Group4, p.6).

Importantly, however, there is not a clear consensus on what this community expects and desires from the company. There is a lack of coordination - with views split between high impact socio-economic projects, and a shopping list of very local, individual requests. There are also tensions between participants from different regions. Those closer to the mining site felt they were the most affected and preferred their concerns to be addressed over others. Participants lower down from the mine site argued they were the most affected and forwarded their grievances to OTML seeking redressing of their claims over other villages. The participants also expressed concern that despite village leaders chosen to represent communities, there were numerous other self-appointed leaders who were making claims directly to the company. It is this, coupled with internal competition and conflicts amongst different village communities, which also impedes the delivery of development projects.

Despite the continued push for increased financial compensation, the indigenous communities continue to face the dilemma, recognizing that monetary compensation cannot be a substitute for means for survival. They realize that any form of monetary compensation will never undo the enduring damage to their environment. As one participant claimed "sago is life" referring to the sago palm tree from which their staple diet is obtained:

...If our sago is destroyed, then our lives are also destroyed. This is why the company must help us now. We know that we cannot get our river and land back, but with some form of company help we can try and support ourselves (Group 3, p. 7).

The observations from our participants under this theme demonstrate the "hate" side of Imbun's (2007) "love-hate" relationship which we raise in our discussion section. 


\section{Theme Two: Benefits of mining}

Despite the contributions that are made by the company, participants differed on what the company should be responsible for, and why.

Many acknowledged the substantial infrastructure contributions, and the macro level benefits these delivered these include - the 150 kilometre Kiunga to Tabubil road, and the road linking the Tabubil hospital and the Kiunga wharf. The participants also acknowledged hospital services, schools and training opportunities. Many also felt the company's contributions at the village level were achieving some positive results. The major concern raised was for the programs to be more extensive - covering a wider area and including a larger population.

...we are happy that the company has built the highway. It makes it easy to travel to Kiunga and Tabubil. Because of the road, people in our village can sell their vegetables in Kiunga. Even though it is still a long way, the road makes it possible to go to Tabubil hospital when our people are sick. For this, we are happy with the company (Group 2, p. 4).

But at the same time the road was seen a problem as well:

...we are happy with the road. Some of our people who own buses and trucks can make some money this way. However, we are not happy about how the company is maintaining the road. They are getting gravel from the polluted river. It gets very dusty and those who travel up the road breathe this dust. We are afraid the people might get sick because the dust might contain pollution and chemicals from the mine waste. It will be good if the company can permanently seal the road (Group 1, p. 4).

On an individual and household basis, however, the respondents stated they did not benefit much from the company. One participant suggested that:

...we are not given any kind of compensation for the damage to the river and our land. The mine area landowners are paid royalties every year. They have a lot of money to spend. The landowners in Tabubil also benefit because the company pays them for using their land. Here, in my place, we are not given anything. The company said they will pay us, and we are still waiting for them (Group 4, p. 2).

For some, the mining companies needed to step up to address negative impacts. The indigenous communities felt tangible benefits and contributions were necessary as compensation for environmental impacts (Imbun, 2007). Mining companies and developers are viewed as responsible for bringing environmental and cultural changes to once pristine and tranquil areas; therefore they should make amends through meeting the expectations of the indigenous communities (Imbun, 2007).

The expectation on education of youth from the mine affected areas was expressed by one participant in the following way:

...not enough of our young people are attending universities. Sometimes the problem is because of no school fees. The company must find a way to help these young people. The company only pays the school fees for a few students. The company must increase this in the mine affected areas so that many of our children can attend universities (Group 3, p. 7).

Others looked to mining companies because of the perceived ineffectiveness of the Government. Most held very negative and highly sceptical attitudes toward the Government. The participants believed the Government was totally ignorant of their development needs. They see the government has having failed in its responsibilities to provide basic services and economic development initiatives 
(Imbun, 2007, Kirsch, 2007). Thus, the local communities view the mining company as the medium that has potential to bring development and would favour the mining company providing more CSR services. Many expressed frustration that the Western Fly River Provincial Government and the national government were given their share of the mines revenues, yet had reinvested very little in the province.

...we know the company is starting to do some important projects now. However, we are worried of what will happen to them after mine closure. To continue these projects, the PNG Government and the PNGSDC must also get involved to help us. This way, the projects can continue to run when the company leaves after mine closure (Group 1, p. 4).

Through this theme we can see the development of the "love" side of Imbun's (2007) "love-hate" relationship.

\section{Theme Three: Mine closure and legacy}

The third theme was an expectation that OTML must provide sustainable socio-economic and financial benefits before the mine closed. The focus is on the future, rather than current initiatives. Many felt that most of the benefits of the mining activity had gone to a minority group - and that the lives of the majority along the Ok Tedi River had hardly changed. A greater say in the distribution of benefits before the mine closed was needed. One tangible example was a form of medical insurance because of the likely continued pollution of the river. One participant suggested:

...we are fearful that people will get many kinds of sicknesses in the future. Already some of our people have the sickness called bladder stone disease. This is a result of the pollution and chemicals in the river. We want the company to establish a long term medical insurance cover for mine affected regions (Group 4, p. 7).

Overwhelmingly, participants put financial compensation as their top priority. It was evident that the local communities wanted adequate financial compensation before mine closure, and there was evidence that local communities were not satisfied with the company's current approach to compensation. One participant suggested:

...money given on a piece meal basis does not allow us to do anything with it. We are only able to consume this money. They must give it to us in lump sum so that we can do something with it such as investments (Group 3, p. 7).

Another participant used the sago tree, a stable diet in the region, to illustrate his concern regarding the current compensation schemes administered by the company.

....sago is the livelihood of the people. If OTML is doing something, they must do so that it lasts a life time just like the sago tree. Otherwise, it is a lost cause. We have the ideas to obtain this, however OTML must listen to us (Group 4, p. 8).

Related to the above grievances were issues associated with promises the company had made to the indigenous communities after the 1996 lawsuit. One that wasn't honoured was a \$US40 million one off payment to indigenous communities. One participant suggested:

...the promises made after the 1996 lawsuit have not been kept. We don't know how much of this money is being paid to us and whether we will ever receive the full amount. This money must be paid to us in full now so that we can do something with the money. (Group 4, p. 8). 
Others suggested the need to upgrade local hospital services - to at least the same standard as the hospital in Tabubil, and that further roading infrastructure was necessary to be completed before the benefits of the mine dried up. A majority of the focus group participants agreed settling in permanent villages was a good concept. However, because there was no road linking the Western Province and the rest of PNG, the participants felt there was no market to sell surplus crops and fruits that were farmed. The participants felt a solution to this problem would be to have a ship that would run along the Ok Tedi and Fly Rivers as a floating market which would stop at designated places to buy agriculture produce from the local communities. The participants expressed a sense of urgency in wanting the company to deliver sustainable projects and benefits before mine closure. Many also felt that what was currently underway, should have been done a long time ago. Thus, they feared that all the recent plans to encourage social and economic development projects may not be achieved before mine closure. These concerns drove demands for greater compensation to enable local communities to take ownership and have direction in making plans for the future. The participants acknowledged they had educated people from the local areas who can provide leadership in making investment decisions and they had ideas on how to achieve sustainable development projects for the community. Therefore, they wanted the company to come forward and make the promised compensation payments in lump sum and let the indigenous communities face the risks and challenges of investment and business. As one participant expressed:

...we know the problems we are going through, and we have the ideas to help ourselves. The company must let us help ourselves by giving the compensation money as a one of lump sum payment and not little by little (Group 4, p. 8).

\section{Discussion and concluding comments}

OK Tedi Mining Company has developed a series of comprehensive corporate policy guidelines to achieve socio-economic developments at both the village and provincial levels. The company maintains that it has engaged the affected communities as key stakeholders in developing solutions to the complex issues, including the containment of increasing pollution levels and identifying key development projects. These development projects are intended to create alternative cash generating opportunities as part of the mine closure plans.

Many of our study participants, however, had reservations about the effectiveness of these projects, and whether the benefits would endure beyond the then planned mine closure in 2013. There is a lack of trust - and a lack of faith in how the company executes its projects. After nearly twenty years of mine operation, they had little to show in terms of socio-economic progress and development.

According to Imbun (2007), communities and governments develop a "love-hate" relationship with the MNMCs - and this type of relationship is apparent in relations between the Lower Ok Tedi indigenous community and OTML. In many ways, the mining company, its operations and outcomes are cherished. When BHP Ltd, OTML's then major shareholder, wanted to close operations in 1996 after the lawsuit, the wider community in the mine affected regions rejected the idea. Despite the anger and frustration exhibited at the company for the years of environmental destruction, the indigenous community still wanted the company to remain.

The focus group participants mirrored the "love- hate" phenomenon - they resented the company and their body language portrayed hatred towards the company. The participants in the four focus groups generally agreed that their environment including riverine and land resources along the river were no longer viable. For the loss of subsistence livelihood, the participants expressed sentiments wanting the company to adequately compensate them. The participants expressed frustration for being neglected for compensation payments while their river was being destroyed. They resented the 
company for polluting their river and causing destruction to the surrounding environment. They were dissatisfied with the slow implementation of community based CSR projects.

Many did, however, "love" the company. The indigenous communities realize that it is OTML that has introduced modernity and the western world. They realise that the mine has led to vital health and education services. They appreciate the infrastructure developments and other economic and social projects which were once non-existent (Imbun, 2007 and Jorgensen, 2006). In many ways, the communities are appreciative of the company's CSR initiatives.

At a macro level, the company's activities are appreciated, but there is a disconnect at the micro level. Initiatives targeting individual villages and households are seen as ineffective and fail to touch the day-to-day realities experienced by affected communities. Many argued that OTML was slow and careless in identifying the needs and expectation of locals, and responding in a timely manner. An example of this was the constant flooding that occurred in the villages due to sediment build up. Many felt that communities are left to address environmental hardships on with limited company assistance. The community based projects were few and far apart, and many doubted that the strategies in place would bring any effective solution to the problems they faced.

Given the gravity of expectations placed on the company regarding CSR projects, one would wonder whether the company would have the financial, human and technical competencies to meet expectations in a limited timeframe before mine closure. The meeting of individual expectations of 30,000 people stretching an area of 180 Kilometres would appear non feasible to the company. Even if the company attempted to resolve issues and meet CSR expectations village by village, it is highly unlikely all villages would be covered before the then projected mine closure in 2013 .

On the company's part, there also appears to be one major impediment in achieving its CSR strategies. Despite the obvious fact that the company has well documented CSR policies (i.e. CMCA agreements) and other CSR corporate guidelines to direct its strategies, the practical implementation of such projects appears to be very slow. The snail's pace in CSR project implementation appears to be an inherent characteristic of OTML. As one senior OTML management official stated "despite the huge wealth and benefits generated by the mine over the many years and the increasing environmental impacts, there is little to show for in terms of social and economic development" (Higgins, 2001, p. $1)$.

\section{References}

Annadale, D, \& Taplin, Ross. (2003). The determinants of mining company response to environmental approvals regulation: A report of Australian research. Journal of Environmental Planning and management, 46(6), 203-218.

Banks, G. (2002). Mining and the environment in Melanesia: Contemporary debates reviewed. The contemporary pacific, 14(1), 39-67.

Beaver, W. (1999). Is the stakeholder model dead? Business Horizons, March/April, 8-12.

Bendell, J. (2000). Terms for endearment: Business, NGOs and sustainable development. Sheffield, UK: Greenleaf.

Bowen, H. R. (1953). Social responsibilities of the businessman. New York: New York University Press.

Bowie, Norman. (1991). New directions in corporate social responsibility. Business Horizons, 34(4), $56-65$ 
Boyatzis, R. (1998). Transforming qualitative information: Thematic analysis and code development. Thousand Oaks, CA: Sage.

Braun, V., \& Clarke, V. (2006). Using thematic analysis in Psychology. Qualitative research in Psychology, 3(2), 77-101.

Breen, A. (2007). PNG mining seminar, Port Moresby [Electronic Version]. Retrieved 25 March 2008 from http://www.oktedi.com/home/oktedi/okTedi/www/reports/news/75/Presentation.pdf

Carroll, A. (1979). A three-dimensional model of corporate performance. Academy of Management Review, 4(4), 497-505.

Carroll, A. (1999). Corporate social responsibility: Evolution of a definitional construct. Business and Society, 38(3), 268-295.

Clarkson, Max. B.E. (1995). A stakeholder framework for analysing and evaluating corporate social performance. Academy of Management Review, 20(1), 92-117.

Dahlsrud, Alexander. (2008). How corporate social responsibility is defined: An analysis of 37 definitions. Corporate social responsibility and environmental management, 15(1), 1-13.

Davidson, C., \& Tolich, M. (2003). Social science research in New Zealand: Many paths to understanding $\left(2^{\text {nd }}\right.$. Ed.). Auckland: Pearson.

Den Uyl, Douglas, J. (1984). The new crusaders: The corporate social responsibility debate. Bowling Green, Ohio: The Social Philosophy and Policy Centre: Bowling Green State University.

Donaldson, Thomas. (1982). Corporations and Morality. Englewood Cliffs: Prentice Hall.

Donaldson, Thomas, \& Preston, Lee. (1995). The stakeholder theory of the corporation: Concepts, evidence, and implications. Academy of Management Review, 20(1), 65-91.

Evans, G. (2001). Human rights, environmental justice, mining futures [Electronic Version], 1-8. Retrieved 19 May 2007 from: www.austlii.edu.au/au/other/HRLRes/2001/14/

Frederick, William C. (1994). From CSR1 to CSR 2. Business \& Society, 33(2), 150-164.

Freeman, R. Edward. (1984). Strategic management: A stakeholder approach. London: Pitman.

Garvin, T, McGee, T, Smoyer-Tomic, K, \& Ato Aubynn, E. (2009). Community-country relations in gold mining in Ghana. Journal of Environmental Management, 90(3), 571-586.

Harper, A., \& Israel, M. (1999). The killing of the fly: State-corporate victimization in Papua New Guinea. Canberra: Resource Management in Asia pacific Program

Hasnas, John. (1998). The normative theories of business ethics: A guide for the perplexed. Business Ethics Quarterly, 8(1), 19-42.

Higgins, R. J. (2001). Ok Tedi: Creating community partnership for sustainable development [Electronic Version]. Retrieved 3 September 2007 from http://www.oktedi.com/reports/reports/54/CIM paper Higgins.pdf 
Imbun, B. Y. (2007). Cannot manage without the significant other: Mining, corporate social responsibility and local communities in Papua New Guinea. Journal of Business Ethics, 73, 177-192.

Imhof, A. (1996). The Big, Ugly Australian goes to OK Tedi. Multinational Monitor. 17(3) 1-7.

Jennings, A. (1995). Environmental devastation: BHP lies about Ok Tedi. Tabubil. Papua New Guinea

Jorgensen, D. (2006). Hinterland History: the Ok Tedi Mine and its cultural consequences in Telefolmin. The contemporary pacific, 18(2), 233-263.

Kalinoe, L., \& Kuwimb, M. (1997). Customary land owners' right to sue for compensation in Papua New Guinea and the Ok Tedi dispute [Electronic Version]. Retrieved on 28 August 2007 from: www.paclii.org/journals/MLJ/1997/4.html.

Kerr, Roger. (1996). The meaning of corporate social responsibility. Paper presented at the AIESEC Corporate Social Responsibility Seminar, Auckland(3 December 1996).

Kirsch, S. (1992). Social impact of the Ok Tedi mine on the Yonggom villages of the North fly. South Hadley, Massachusetts: Mount Holyoke College

Kirsch, S. (2007). Indigenous movements and the risks of counterglobalization. American ethnologist, $34(2), 303-321$.

Margolis, J, \& Walsh, J. (2003). Misery loves companies: Re-thinking social initiatives by business. Administrative Science Quarterly, 48, 268-305.

McIntosh, M, Thomas, R, Leipziger, D, \& Coleman, G. (2003). Living corporate citizenship: Strategic routes to socially responsible business. London: FT and Prentice Hall.

Michelon, G, Boesso, G, \& Kumar, K. (2013). Examining the Link between Strategic Corporate Social Responsibility and Company Performance: An Analysis of the Best Corporate Citizens. Corporate Social Responsibility \& Environmental Management, 20(1), 81-94.

Mitchell, R, Agle, B, \& Wood, D. (1997). Toward a theory of stakeholder identification and salience: Defining the principle of who and what really counts. Academy of Management Review, 22(4), 853886.

Morgan, D. L. (1993). Successful focus groups. Advancing the state of the art. Newbury Park: Sage Publications.

Morgan, D. L. (1997). Focus groups as qualitative research (second ed.). Thousand Oaks: Sage Publications, Inc.

Morrison, J. (2007). Mining and sustainable development [Electronic Version], 1-35. Retrieved 18 May 2007

from: www.sustainability.murdoch.edu.au/casestudies/case

OK Tedi Mining Limited. (2007). Ok Tedi: Our Project, Our Challenge. Tabubil, Western Province, Author.

Preston, L. (1990). Stakeholder management and corporate performance. Journal of Behavioural Economics, 19(4), 361-375. 
Wartick, Steven, L, \& Cochrane, Philip, L. (1985). The evolution of the corporate social performance model. Academy of Management Review, 10(4), 758-769.

Windsor, D. (2001). Corporate citizenship: evolution and interpretation. In J. Andriof \& M. McIntosh (Eds.), Perspectives on corporate citizenship (pp. 26-51). Sheffield: Greenleaf.

Windsor, D. (2006). Corporate social responsibility: Three key approaches. Journal of Management Studies, 43(1), 93-114.

Wood, D. (1991a). Corporate social performance revisited. Academy of Management Review, 16(4), 691-718.

Wood, D. (1991b). Toward improving corporate social performance. Business Horizons, July-August, 66-73.

Wry, Tyler. (2009). Does business and society scholarship matter to society? Pursuing a normative agenda with critical realism and neoinstitutional theory. Journal of Business Ethics.

Yakovleva, N. (2005). Corporate Social Responsibility in the Mining Industries. Hampshire: Ashgate Publishing Limited. 


\section{Appendix A}

Map of the Ok Tedi Mine, Ok Tedi River, Tabubil Town and Kiunga Town.

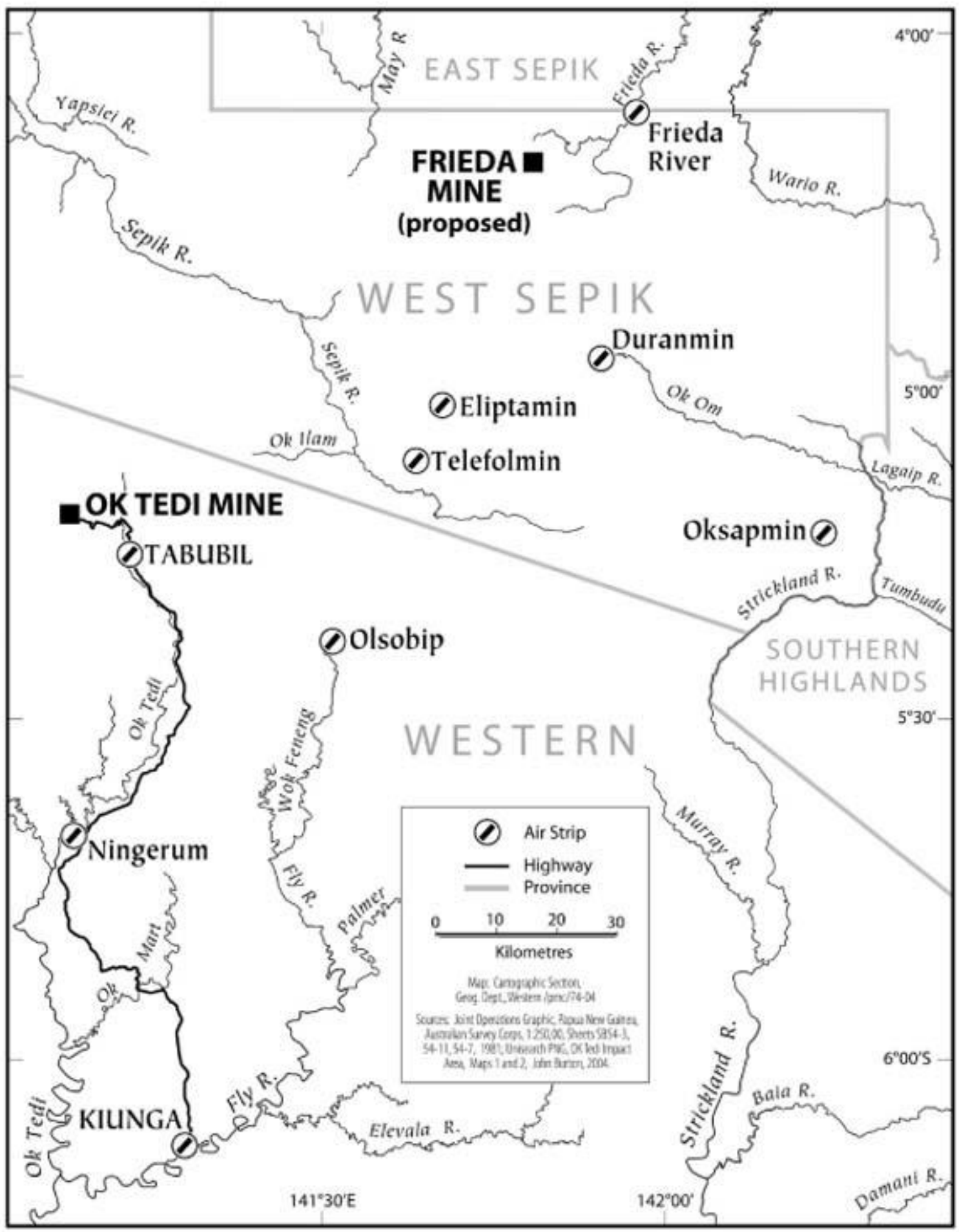




\section{Appendix B}

Ok Tedi, Kiunga and Western Province in perspective to PNG.

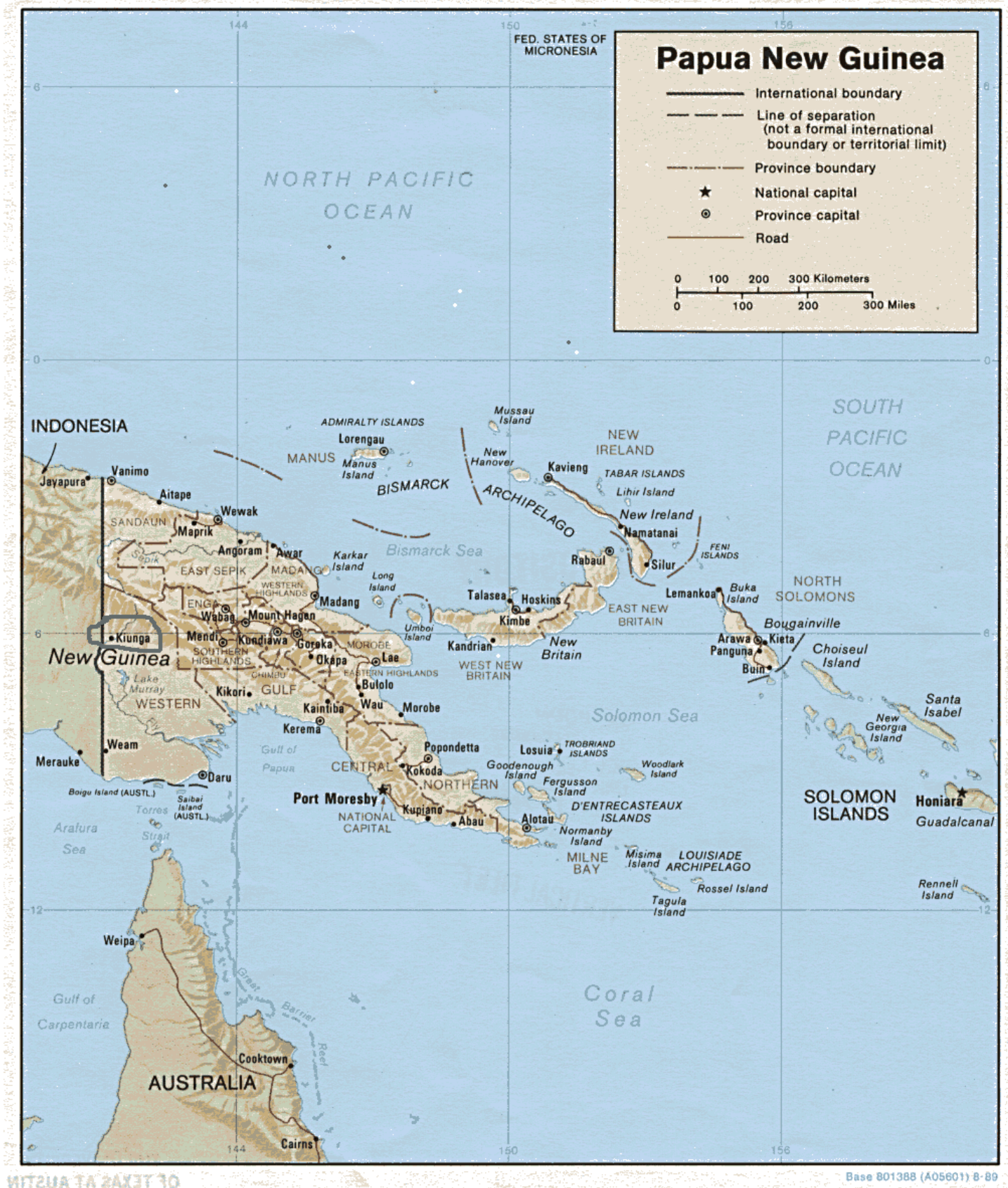




\section{Appendix C}

\section{Focus Group Questionnaire}

(1) What is the best (positive) thing(s) the company has done for the people in your village and how has this affected your life?

(2) What are your views on the way the company has operated and what do you think the company should do?

(3) What is the worst thing(s) the company has done and how has this affected your life?

(4) What are the things you believe the mining company can do differently in terms of its strategies that are directed at you?

(5) How has your life changed over the last 20 years since the company commenced mining operations?

(6) What is the condition of the river and how has this affected your lives?

(7) Do you think the village has changed during the mining operation and if so, how has it changed and in what ways has the change affected the villagers?

(8) What are your views on the company's compensation payment for the environmental damage? 
